\title{
AIRCRAFT DIESEL ENGINE TURBOCOMPOUND OPTIMIZED
}

\author{
Giampiero Donnici $^{1}$, Ilaria Rocchi ${ }^{2}$ and Eugenio Pezzuti ${ }^{3}$ \\ ${ }^{1}$ DIN - Dipartimento di Ingegneria Industriale \\ ALMA MATER Università di Bologna \\ Viale Risorgimento, 2 - 40136 Bologna, Italy \\ ${ }^{2,3}$ Faculty of Engineering \\ University of Rome Tor Vergata \\ via del Politecnico, 1 - 00133 Rome, Italy \\ e-mail: pezzuti@mec.uniroma2.it
}

\begin{abstract}
In order to optimize the design of the thermodynamic cycle of a turbine (Brayton cycle) for using modern common rail as an "active" combustion chamber it was intended to write the present paper.

About the present case, the "active" combustion chamber produces a large amount of the mechanical energy that drives the fan. The incoming air is compressed by the compressor, then it is refrigerated and inputted in the diesel engine. A high pressure common rail system optimizes the combustion in the diesel combustion chamber and the expansion begins inside the diesel engine. At the exhaust of the combustion chamber a turbine completes the expansion of the hot gases. A nozzle accelerates the exhaust from the turbine to increase the overall thrust.
\end{abstract}

The mechanical energy from the diesel and from the turbine powers the compressor and the fan.

Received: June 23, 2014; Accepted: August 22, 2014

Keywords and phrases: feasible optimum Diesel-Brayton cycle. 
The system can be seen as a turbocharged diesel engine with the turbocharger that outputs energy to the turbofan, increasing the output power and or the efficiency. A diesel-turbine compound can be realized in this way.

The coupling of the two systems may be obtained in several different ways. The simplest is to put on the same shaft the compressor, the diesel crankshaft and the turbine. In front of the compressor a speed reducer drives the fan.

A second example is to connect the turbine and the diesel on to electric generators. Electric engines are connected to the compressor and to the fan.

The traditional turbodiesel has the compressor coupled to the turbine, and the diesel engine that moves the fan. In this latter case, however, the turbine does not energize the fan. Many other hybrid and nonhybrid solutions are possible. The problem is to optimize temperatures, pressures and rpm to the different machines that form the compound.

The availability of many experimental data for diesel and turbines makes it possible to obtain a design of a "true" feasible optimum Diesel-Brayton cycle.

This efficiency figure justifies the huge manufacturing and development costs of these turbocompound engines [1-4].

\section{Introduction}

The increasing speculation on combustion prices has revived technical solutions that where abandoned due to costs and reliability.

The advantage of combined cycles is the possible increase in thermodynamic efficiency. This solution was abandoned in the aircraft market with the supremacy of turbofan, turboshaft and turbojet engines.

The price of combined cycles is a complicate design, increase of weight and cost and reduced reliability.

Also, the overall dimension of the system may make the turbocompound installation impractical. 
The best and more efficient piston engine available is the diesel common rail engine. With its huge efficiency (more than 50\%), very high combustion temperature and pressure (up to $2800 \mathrm{~K}$ and $30 \mathrm{MPa}$ ) and the high specific power due to high combustion speed it is now possible to run diesel engines up to $10,000 \mathrm{rpm}$.

The modern diesel engine has already a turbocharger that also improves high altitude performances.

However, this turbocharger usually does not output mechanical energy. Some cases of electric generators coupled to turbocharger are available (Caterpillar, etc.), but they are conceived more to increase diesel performance than to obtain a true hybrid solution [5-10].

On the other side, the off-the-shelf reliable diesel engine has several temperature limitations. The intake air should be cooled down to $323 \mathrm{~K}$ $\left(50^{\circ} \mathrm{C}\right)$ to improve volumetric efficiency and the exhaust should not exceed $1323 \mathrm{~K}\left(1050^{\circ} \mathrm{C}\right)$ due to head design and cooling.

Turbines have also limitations. The maximum intake temperature is about $1950 \mathrm{~K}\left(1677^{\circ} \mathrm{C}\right)$ with a more common value of $1700 \mathrm{~K}\left(1427^{\circ} \mathrm{C}\right)$. Intake pressure and velocity fields should be very constant and close to the optimum since turbines are essentially steady state machines.

Compressor may reach very high value up to $65: 1$ or more, however, a practical limit is about 46:1 in order to avoid and enormous increase in dimension and weight.

Other issues may regard, fan, intakes and nozzles. However, this paper is a thermodynamic study of the cycle and does not deal with this "accessories" [11-18].

This paper is organized with these following steps:

- A brief introduction to Brayton cycle limitations and choices.

- A description of the state-of-the-art turbofan.

- A description of the state-of-the-art common rail diesel engine. 
- A paragraph about the combination of the diesel and the turbine and the individuation of the optimization parameters.

- An optimum Diesel-Brayton cycle and its efficiency.

\section{A Brief Introduction to Brayton Cycle Limitations and Choices}

The turbofan engine cycle can be easily split into main parts [19-29] [30, 31]:

(1) The core or primary cycle done by the primary flux which begins at the intake (outside air conditions) and ends at the exhaust nozzle (after the low pressure turbine). This cycle is the energizer, since it outputs all the power needed for the fan. This cycle also outputs a very limited thrust.

(2) The secondary cycle that compresses the bypass flux then generates the thrust.

So it is possible to consider the core stream process like a simple cycle gas turbine, paying attention about the compression of the incoming air from ambient conditions and the augmentation of the temperature.

With this simplification, various variables to enhance the performances of the engine cycle can be considered.

The simplest model of the gas turbine is the parametric study of the cycle using constant gas properties.

So the possibility to increase the burner exit temperature can be considered, with the option of constant and variable pressure ratio. Anyway, as an example, by limiting the pressure ratio at 40 , the potential increment regarding the thermal efficiency is not so good with a EGT (Exhaust Gas Temperature) over $2000 \mathrm{~K}$ [17].

Exhaust gas from fossil fuels, like kerosene (Jp4, Jp8, jet A1..) or diesel, that uses air as oxidizer, has approximately the same gas constant of dry air. Therefore, it may be acceptable to consider compressor and turbine gas constants equal to the one of dry air, but their isotropic exponents are not constant and change significantly with the temperature. 
Normally, the thermal efficiency is defined as

$$
\eta_{t h}=\frac{H_{T}-H_{C}}{H_{B}}
$$

where

$H_{T}$ is the specific turbine shaft power,

$H_{C}$ is the specific compressor shaft power-level,

$H_{B}$ is the amount of energy given by the burner to the cycle.

It is possible to use another definition:

$$
\eta_{t h}=\frac{H_{T}-H_{C}}{W_{F} \cdot F H V}
$$

where

$W_{F}$ means the fuel flow,

FHV the lower calorific value (LCV),

the result is that there is an optimum of thermal efficiency at temperatures below the stoichiometric limit.

So the maximum thermal efficiency is found with fuel-air ratios about the $50 \%$ of the stoichiometric value [17].

To make the calculation more accurate it must be considered the quantity of cooling air needed by the turbine and the losses related to it. So, once this quantity is found, the cycle shows that the equivalence ratio at the optimum thermal efficiency is $60 \%, 10 \%$ higher than the un-cooled cycle [17]. 
3. The Thermodynamic Cycle of a State-of-the-art Low-bypass Turbofan@15360 m ISA+0

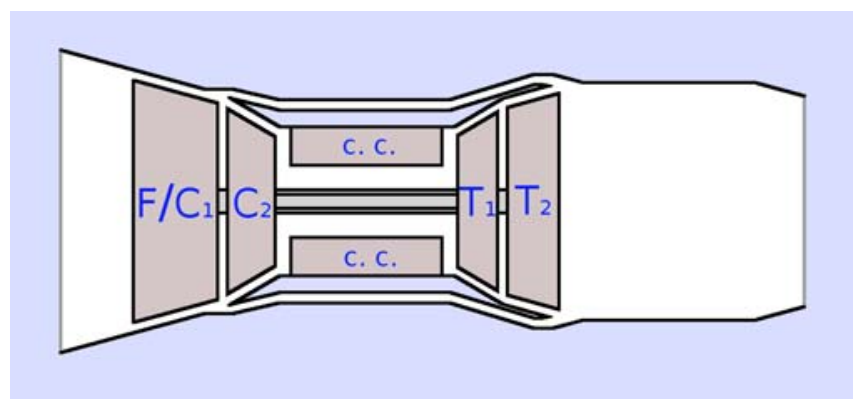

Figure 1. Scheme of a typical turbofan engine.

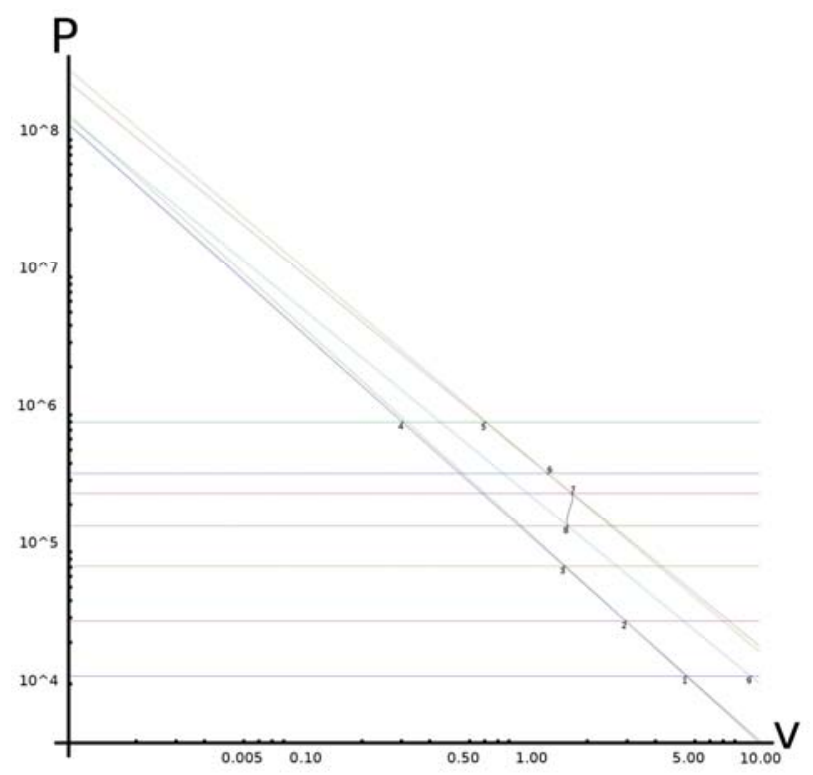

Figure 2. PV logarithmic diagram of a very high performance military turbofan engine. 


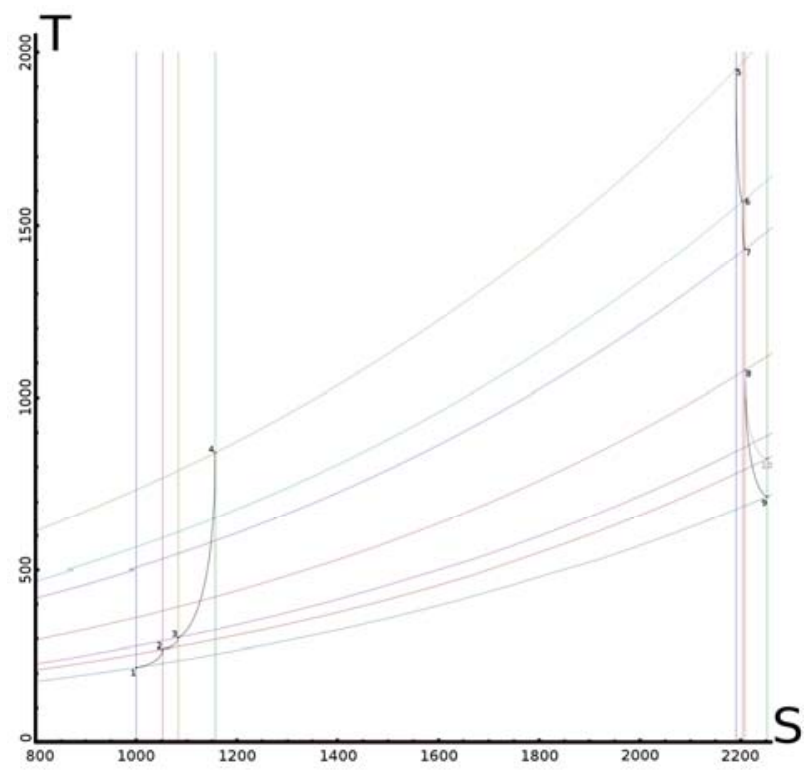

Figure 3. TS diagram of a very high performance military turbofan engine.

Table 1. Military low-bypass turbofan engine @ 15360 m ISA+0

\begin{tabular}{|l|c|c|c|}
\hline Pressure at intake (ISA+0) @ $15360 \mathrm{~m}$ & {$[\mathrm{~Pa}]$} & $\mathrm{p} 1$ & 11380 \\
\hline Temperature at intake (ISA+0) @ $15360 \mathrm{~m}$ & {$[\mathrm{~K}]$} & $\mathrm{T} 1$ & 216.65 \\
\hline Pressure after the intake duct & {$[\mathrm{Pa}]$} & $\mathrm{p} 2$ & 28449.7 \\
\hline Temperature after the intake duct & {$[\mathrm{K}]$} & $\mathrm{T} 2$ & 293.1 \\
\hline Pressure after low pressure compressor & {$[\mathrm{Pa}]$} & $\mathrm{p} 3$ & 71124.2 \\
\hline Temperature after low pressure compressor & {$[\mathrm{K}]$} & $\mathrm{T} 3$ & 391.3 \\
\hline Efficiency of low pressure compressor & {$[-]$} & etacompbp & 0.88 \\
\hline Work of low pressure compressor $x$ kg of dry air & {$[\mathrm{J}]$} & Lcompbp & 99194.2 \\
\hline Pressure after high pressure compressor & {$[\mathrm{Pa}]$} & $\mathrm{p} 4$ & 796591 \\
\hline Temperature after high pressure compressor & {$[\mathrm{K}]$} & $\mathrm{T} 4$ & 842 \\
\hline Efficiency of high pressure compressor & {$[-]$} & etacompap & 0.88 \\
\hline Work of high pressure compressor $x$ kg of dry air & {$[\mathrm{J}]$} & Lcompap & 490182 \\
\hline Temperature after the burner (EGT) $[\mathrm{K}]$ & {$[\mathrm{K}]$} & $\mathrm{T} 5$ & 1950 \\
\hline Efficiency of high pressure turbine & {$[-]$} & etaturbap & 0.96 \\
\hline Temperature after high pressure turbine & {$[\mathrm{K}]$} & T6 & 1569.91 \\
\hline Pressure after high pressure turbine & {$[\mathrm{Pa}]$} & p6 & 337780 \\
\hline
\end{tabular}




\begin{tabular}{|l|c|c|c|}
\hline Work of high pressure compressor $x$ kg of dry air & {$[\mathrm{J}]$} & Lturbap & 490180 \\
\hline Efficiency of low pressure turbine & {$[-]$} & etaturbap & 0.96 \\
\hline Pressure after low pressure turbine & {$[\mathrm{Pa}]$} & $\mathrm{T} 7$ & 1431.9 \\
\hline Pressure after low pressure turbine & {$[\mathrm{Pa}]$} & $\mathrm{p} 7$ & 242114 \\
\hline Work of high low compressor $x$ kg of dry air & {$[\mathrm{J}]$} & Lturbbp & 99204.3 \\
\hline Efficiency of nozzle & {$[-]$} & etaugello & 0.95 \\
\hline Temperature of mix bypass air and low press turbine exhaust & {$[\mathrm{K}]$} & T8 & 793.7 \\
\hline Temperature of mix bypass air and low press turbine exhaust & {$[\mathrm{Pa}]$} & p8 & 139.2 \\
\hline Temperature exit nozzle & {$[\mathrm{K}]$} & T9 & 418.5 \\
\hline Overall cycle efficiency & {$[-]$} & etathr & 0.42 \\
\hline
\end{tabular}

The thermodynamic cycle and the data of a state-of-the-art military lowbypass turbofan without aftercooler are summarized in Table 1 and Figures 1,2 and $3[23,24,30]$.

\subsection{A description of the state-of-the-art common rail diesel engine cycle}

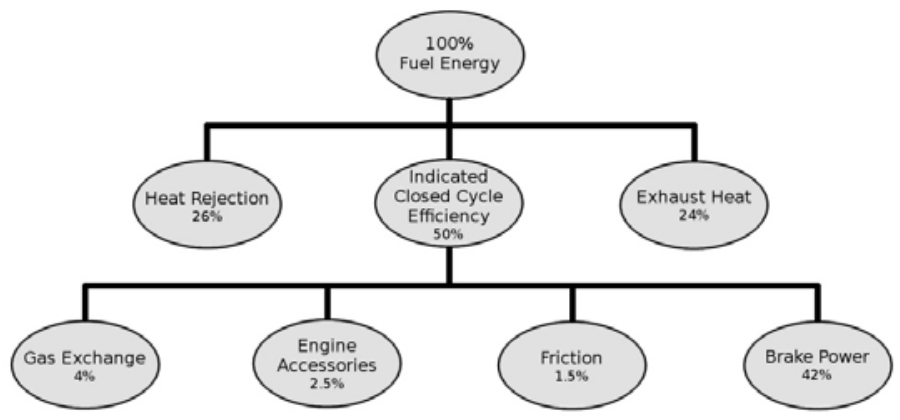

Figure 4. Energy audit for a typical diesel engine [Source: Adapted form Vinod Duggal, Cummins, Inc., "Industrial Perspectives of the 21st Century Truck Partnership” presentation to the committee, Dearborn, Mich., 6 April 2009, Slide 14 (and TIAX 2009, p 4-3, Table 4-1)].

\section{The German experience}

In Germany, the Anglo German DAIR (Diesel Air GmbH), which is located in Dessau, has proposed a new four-cylinder two-stroke diesel where there is the pattern taken from the construction scheme of the Jumo 207, produced by Junkers in the 40s. 
The engine has in fact the opposite cylinder heads with in the middle and the two crankshafts on both sides, connected by a gear box.

The new DAIR one is similar in size to the Continental O 200, which the intention of the manufacturer might candidates as a substitute, with the same provision of the attachment points. In addition It is made of aluminum and has a dry weight of 90 kg, develops a power of $100 \mathrm{HP} @ 2,500 \mathrm{rpm}$, and can be fed by diesel or kerosene aviation.

The fuel injection pump up to 600 bar is from the automobile industry, as well as the turbocharger.

The engine, which has a displacement of 1.8 liters, is liquid cooled through two small radiators.

The problem of the DAIR, as of the Jumo 207, that was a complete failure, is the high loads on the connecting gearbox.

Another WWII Jumo derived German engine is the 2 stroke-directinjection radial Zoche aero-diesel. Charge air pressure is generated by a combination of a highly efficient mechanical blower and a newly developed advanced turbocharger, reducing power loss at altitude. The quadruple flow compressor is integral to the monoblock intercooler, resulting in a very high efficiency of the turbocharger and intercooler installation. The intake manifold is an integral part of the crankcase casting. The fuel injection pump together with its feed pump, the fuel filter and all connecting plumbing are integrated into the crankcase assembly, further reducing the parts count and improving reliability. This WWII engine had crack problems had crack problems in the basement that seems to have been solved in the modernized Zoche.

The Thielert Centurion diesel engines have developed and aeronautical certified the four-cylinder Common Rail Mercedes, 1689 cc, which equipped the Mercedes A 170 CDI (W168) until 2005.

From this modern four-stroke diesel turbocharger and an intercooler with a Garrett, the Thielert has extrapolated two aircraft engines: the $110 \mathrm{TAE}$ 110 HP maximum at take-off @ 3,675 rpm, which is used as a technology 
demonstrator, and the most powerful turbodiesel TAE 125, 95 continues horsepower @3,400rpm and 125 to take off, @ 3,800rpm.

Another Mercedes derivative is the Austrian Austro Engine company with its Wankel and diesel engines. The most common diesel engine of this company is the A300 with $168 \mathrm{HP} @ 3,880 \mathrm{rpm}$ that is direct derivation of the Mercedes A 200CDI (W169) in production until 2012.

Both Thielert and Austro engines use a PSRU (Propeller Speed Reducer Unit) with integrated damper.

The French research: the SR 305

At the Le Bourget Air Show in the '97 the French Societé de Motorisations Aéronautiques (SMA), formed by the Renault Sport and Socata (Morane), presented the engineering prototype MR 250, a four cylinder 5-liter direct injection diesel engine with 250 HP @ 2,000 rpm.

Then they announce two other models of this family of engines: MR 180 and MR 300, respectively, 180 and 300 horses.

After three years of experimentation on various Socata aircraft, in April 2001 the SMA has finally obtained the European type certification (valid in the 33 countries belonging to the JAA), a new engine derived from the first ones. It is the SR 305, four cylinder four-stroke turbocharged, 230HP @ $2,200 \mathrm{rpm}$, with direct coupling of the propeller to the crankshaft.

\section{The Nasa GAP project}

In April 1997, NMA and Teledyne Continental Motors (TCM) signed a cooperation agreement for the development of a next generation two-stroke turbocharged diesel engine that can facilitate a relaunch of the American General Aviation thanks its advanced (and ambitious) features: fuel consumption reduced by 25 percent compared to a conventional engine, a reduction to half of the purchase price, an increase in revision times of 75 percent and a very low level of the exhaust emissions.

The program, called GAP (General Aviation Propulsion), received special funding from government agencies and membership of major aviation 
companies such as Cirrus and Lancair, for the study of new cells of aircraft specifically designed for the engine, and Hartzell, for the realization of a special three-bladed propeller with high efficiency and extremely silent.

The engine, which has a displacement of 3.9 liters and develops $200 \mathrm{HP}$ @ 2,200 rpm with a 18:1 compression ratio, is provided with a brand new monoblock where they are brought together heads, cylinders and main bearings of the crankshaft, and is cooled with water solution and propylene glycol.

\section{Developments of the Fiat Research Centre - Dieseljet}

The Orbassano CRF (TO) has developed a common rail diesel engines for aeronautical use. It is a derivative of the Fiat $1.9 \mathrm{JTD}-8 \mathrm{~V}$. The decision to take advantage of the most advanced technology expressed by the Fiat 1.9 JTD is driven not only by its immediate availability, but from a careful economic evaluation. Table 2 summarizes the current state of the research on aeronautical diesel:

Table 2. A few available aero-diesels

\begin{tabular}{|c|c|c|c|c|c|c|}
\hline Typology & $\begin{array}{c}\text { No. of } \\
\text { cylinders and } \\
\text { configuration }\end{array}$ & $\begin{array}{c}\text { Displacement } \\
\text { and type of } \\
\text { cycle }\end{array}$ & $\begin{array}{c}\text { Power @ } \\
\text { crankshaft speed } \\
\text { [HP @ rpm] }\end{array}$ & $\begin{array}{c}\text { Weight } \\
{[\mathrm{kg}]}\end{array}$ & $\begin{array}{c}\text { Weight/power } \\
\text { ratio [kg/HP] }\end{array}$ & $\begin{array}{c}\text { Cooling } \\
\text { system }\end{array}$ \\
\hline $\begin{array}{c}\text { Continental } \\
\text { CSD 283 }\end{array}$ & 4 Boxer & $4,7002 \mathrm{~S}$ & $200 @ 2,200$ & 136 & 0.68 & Liquid \\
\hline Delta Hawke & $4 \mathrm{~V}\left(90^{\circ}\right)$ & $3,3002 \mathrm{~S}$ & $200 @ 2,700$ & 123 & 0.61 & Liquid \\
\hline $\begin{array}{c}\text { Lycoming } \\
\text { TDIO-360 }\end{array}$ & 4 Boxer & $5,9004 \mathrm{~S}$ & $205 @ 2,700$ & 136 & 0.67 & Air \\
\hline $\begin{array}{c}\text { Morane Renault } \\
\text { MR 200 }\end{array}$ & 4 Boxer & $5,0004 \mathrm{~S}$ & $200 @ 2,000$ & 144 & 0.72 & Air \\
\hline $\begin{array}{c}\text { Zoche ZO } \\
01 \mathrm{~A}\end{array}$ & 4 Radial & $2,6604 \mathrm{~S}$ & $150 @ 2,500$ & 84 & 0.56 & Air \\
\hline DAIR 100 & 4 Opposite & $1,8004 \mathrm{~S}$ & $100 @ 2,500$ & 90 & 0.8 & Liquid \\
\hline $\begin{array}{c}\text { Thielert } \\
\text { TAE } 125\end{array}$ & 4 in line & $1,6804 \mathrm{~S}$ & $125 @ 3,800$ & 118 & 0.7 & Liquid \\
\hline $\begin{array}{c}\text { Austro Engine } \\
\text { A300 }\end{array}$ & 4 in line & $2,0004 \mathrm{~S}$ & $168 @ 3,880$ & 185 & 0.9 & Liquid \\
\hline $\begin{array}{c}\text { Dieseljet 1,9 } \\
\text { JTD }\end{array}$ & 4 in line & $1,9004 \mathrm{~S}$ & $165 @ 3,800$ & 175 & 0.9 & Liquid \\
\hline
\end{tabular}




\subsection{A paragraph about the combination of the diesel and the turbine and the individuation of the optimization parameters}

\section{Supercharged diesel engines}

The supercharged diesel engine usually uses a compressor, driven mechanically by a turbine, which compresses the air that is supplied to the piston engine. This configuration improves the power output because the compressor uses the energy available from exhaust gases.

The overall efficiency of this cycle is determined by the inlet turbine temperature and the compressor pressure ratio. The results are depicted in Figures 5 and 6 . However, the increase of the turbine inlet temperature decreases the overall efficiency.

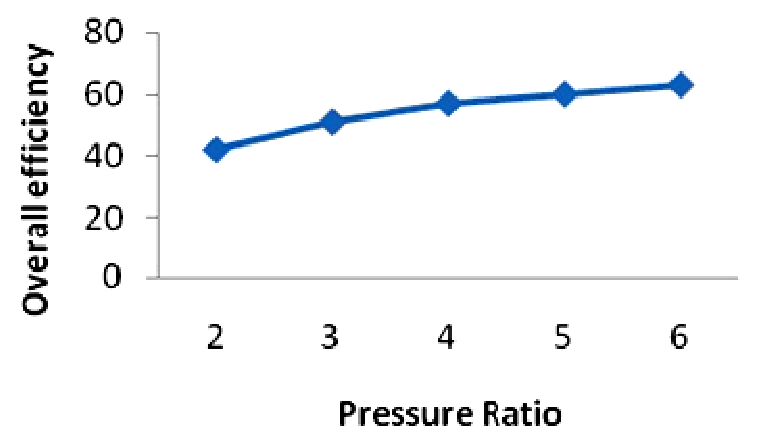

Figure 5. Turbodiesel efficiency with compressor pressure ratio.

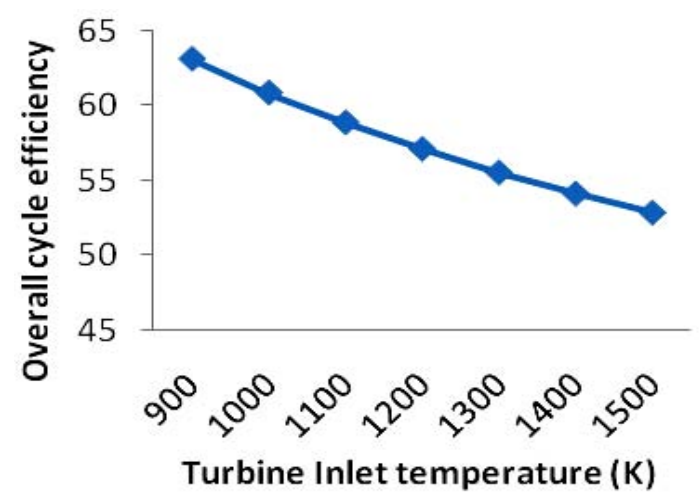

Figure 6. Turbodiesel efficiency with exhaust temperature. 
The optimum Diesel-Brayton turbocompound fan cycle and its efficiency (Figure 7)

It is possible to calculate the optimum turbocompound fan cycle efficiency by assuming very few basic data summarized in Table 3.

These are:

Table 3. Basic assumptions of turbocompound cycle

\begin{tabular}{|l|c|c|}
\hline Maximum allowable diesel chamber pressure & 280 & {$[\mathrm{bar}]$} \\
\hline Maximum allowable diesel chamber temperature & 2800 & {$[\mathrm{~K}]$} \\
\hline Compressor efficiency & 0.88 & {$[-]$} \\
\hline Piston compressor efficiency & 0.8 & {$[-]$} \\
\hline Piston expansion efficiency & 0.9 & {$[-]$} \\
\hline Turbine efficiency & 0.96 & {$[-]$} \\
\hline
\end{tabular}

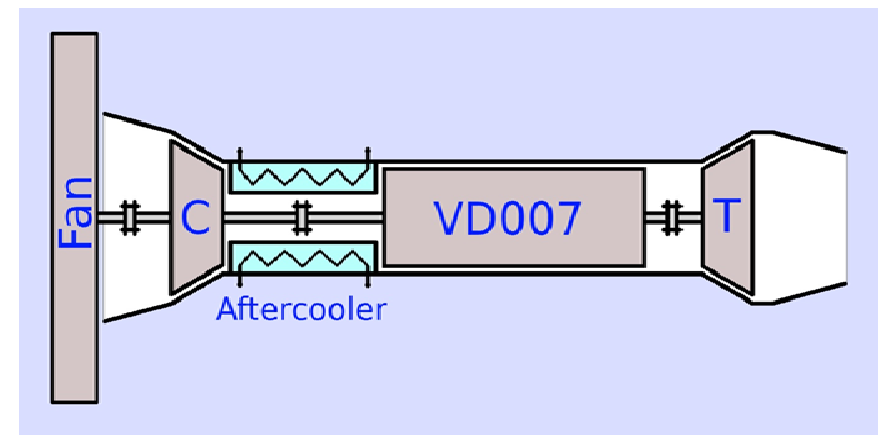

Figure 7. Scheme of the Diesel-Brayton turbocompound engine.

The method of [22] can be adopted for the diesel cycle. The only variable is then the compressor ratio.

The optimum was found to be $18.4: 1$, that requires a multi-stage axial compressor.

The results are summarized in Table 4. 


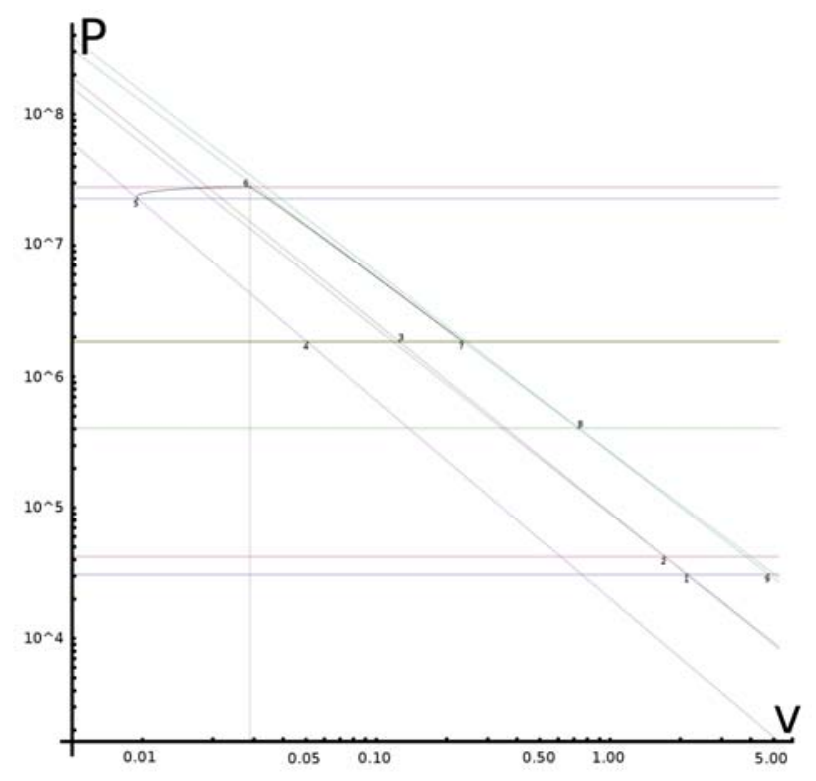

Figure 8. Pressure/volume logarithmic diagram of the turbocompound engine.

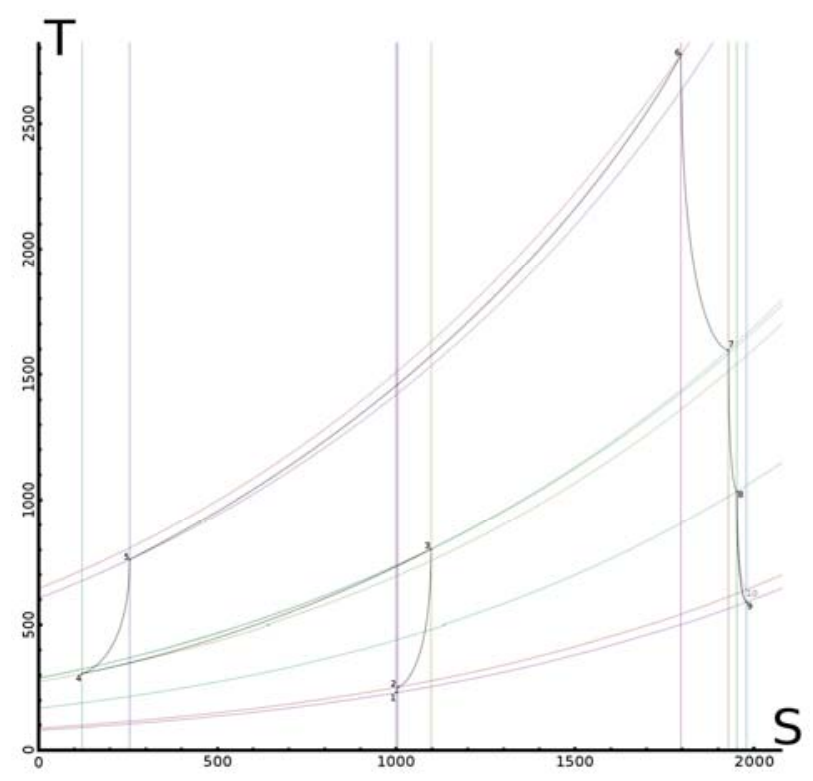

Figure 9. Temperature/entropy diagram of the turbocompound engine. 
Table 4. Optimum turbocompound results

\begin{tabular}{|c|c|c|c|}
\hline Pressure at intake (ISA +0$)$ & {$[\mathrm{Pa}]$} & $\mathrm{p} 1$ & 30742.5 \\
\hline Temperature at intake (ISA +0$)$ & {$[\mathrm{K}]$} & $\mathrm{T} 1$ & 229.65 \\
\hline Pressure after intake duct & {$[\mathrm{Pa}]$} & p2 & 42253.6 \\
\hline Temperature after intake duct & {$[\mathrm{K}]$} & $\mathrm{T} 2$ & 251.944 \\
\hline Pressure after compressor & {$[\mathrm{Pa}]$} & p3 & $1.84211^{*} 10^{\wedge} 6$ \\
\hline Temperature after compressor & {$[\mathrm{K}]$} & T3 & 802.6 \\
\hline Efficiency compressor & {$[-]$} & etacomp & 0.88 \\
\hline Work compressor $x$ kg dry air & {$[\mathrm{J}]$} & Lcomp & 585964 \\
\hline Pressure after aftercooler & {$[\mathrm{Pa}]$} & $\mathrm{p} 4$ & $1.83211^{*} 10^{\wedge} 6$ \\
\hline Temperature after aftercooler & {$[\mathrm{K}]$} & $\mathrm{T} 4$ & 323.15 \\
\hline $\begin{array}{l}\text { Pressure after piston compression (combustion } \\
\text { begins) }\end{array}$ & {$[\mathrm{Pa}]$} & p5 & $2.29013^{*} 10^{\wedge} 7$ \\
\hline $\begin{array}{l}\text { Temperature after piston compression (combustion } \\
\text { begins) }\end{array}$ & {$[\mathrm{K}]$} & T5 & 759.8 \\
\hline Piston compression efficiency & {$[-]$} & etapist & 0.80 \\
\hline Work piston compression $x$ kg dry air & {$[\mathrm{J}]$} & Lpist & 467203 \\
\hline Peak combustion pressure & {$[\mathrm{Pa}]$} & p6 & 28000000 \\
\hline Peak combustion temperature & {$[\mathrm{K}]$} & T6 & 2773.15 \\
\hline Pressure at turbine inlet & {$[\mathrm{Pa}]$} & $\mathrm{p} 7$ & $1.85211^{*} 10^{\wedge} 6$ \\
\hline Piston expansion efficiency & {$[-]$} & etacil & 0.90 \\
\hline Work piston expansion $x$ kg dry air & {$[\mathrm{J}]$} & Lcil & $1.64819 * 10^{\wedge} 6$ \\
\hline Temperature at turbine inlet & {$[\mathrm{Pa}]$} & $\mathrm{T} 7$ & 1511.67 \\
\hline Efficiency turbine & {$[-]$} & etaturb & 0.96 \\
\hline Pressure after turbine & {$[\mathrm{Pa}]$} & p8 & 405900 \\
\hline Work turbine $x$ kg dry air & {$[\mathrm{J}]$} & Lturb & 585914 \\
\hline Efficiency nozzle & {$[-]$} & etaugello & 0.95 \\
\hline Temperature at nozzle exit & {$[\mathrm{K}]$} & T9 & 511.5 \\
\hline Diesel cycle efficiency & {$[-]$} & etadiese & 0.47 \\
\hline Compound cycle efficiency & {$[-]$} & etacomp & 0.70 \\
\hline
\end{tabular}

\section{Conclusions}

In the present paper, a Diesel-Brayton turbocompound fan engine was compared with a state-of-the-art turbofan. 
The turbocompound Diesel-Brayton engine could be the best option with the actual fuel costs, since efficiency up to $70 \%$ may be obtained.

Further increase in efficiency may be obtained by a Meredith effect cooling system both for engine and aftercooler [19].

However, the turbocompound engine is quite complicated and it may require large investments in order to obtain reliability figure comparable with modern turbofans.

\section{References}

[1] D. Kuchemann and J. Weber, Aerodynamics of Propulsion, McGraw-Hill, 1953.

[2] W. M. Kays and A. L. London, Compact Heat Exchanger, McGraw-Hill, 1955.

[3] S. F. Hoerner, Fluid Dynamic Drag, Hoerner, 1965.

[4] B. Gothert, The drag of airplane radiators with special references to air heating, NACA report no. 896, 1939.

[5] H. Winter, Contribution to the theory of the heated duct radiator, NACA report no. 893, 1939.

[6] F. W. Meredith, Note on the cooling of aircraft engines with special references to ethylene glycol radiators enclosed in ducts, British A. R. C. Memorandum no. 1683, 1935.

[7] A. Weise, The conversion of energy in a radiator, NACA report no. 869, 1938.

[8] W. J. Nelson, K. R. Czarnecki and R. D. Harrington, Full-scale wind-tunnel investigation of forward underslung cooling-air ducts, NACA report no. L115, 1944.

[9] K. R. Czarnecki and W. J. Nelson, Wind-tunnel investigation of rear underslung fuselage ducts, NACA report no. L438, 1943.

[10] Ames Research Staff, Equations, tables and charts for compressible flow, NACA report no. 1135, 1953.

[11] Johnston J. Ford, Review of flight tests of NACA C and D cowlings on the XP-42 airplane, NACA-report-771, 1943.

[12] NASA-TN-1026.

[13] AIAA-86-2693, Aerodynamic Design of Low Speed Aircraft with a NASA Fuselage/Wake-propeller Configuration, October 20-22, 1986, Dayton, Ohio. 
[14] John T. Lowry, The Bootstrap Approach to Aircraft Performance, Part Two, Constant-speed Propeller Airplanes, December 12, 1999.

[15] Tsagi, Spinning the fuselage to save fuel. www.flightglobal.com/.../russian-tsagi-spinning-the-fuselage-to-save-fuel.

[16] L. Piancastelli and M. Pellegrini, The bonus of aircraft piston engines, and update on the Meredith effect, Int. J. Heat Tech. 25(2) (2007), 51-56.

[17] J. Kurzke, Achieving maximum thermal efficiency with the simple gas turbine cycle, MTU Aero Engines, Dachauer Str. 665, 80995 München, Germany.

[18] R. C. Wilcock, J. B. Young and J. H. Horlock, Gas properties as a limit to gas turbine performance, ASME GT-2002-30517, 2002.

[19] L. Piancastelli, G. Caligiana, Frizziero Leonardo and S. Marcoppido, Piston engine cooling: an evergreen problem, 3rd CEAS Air \& Space Conference-21st AIDAA Congress-Venice (Italy), 24th-28th October 2011.

[20] L. Piancastelli, L. Frizziero, E. Morganti and A. Canaparo, Fuzzy control system for aircraft diesel engines, Int. J. Heat Tech. 30(1) (2012), 135-140.

[21] L. Piancastelli, L. Frizziero, S. Marcoppido and E. Pezzuti, Methodology to evaluate aircraft piston engine durability, Int. J. Heat Tech. 30(1) (2012), 89-92.

[22] L. Piancastelli and D. Francia, A very simple and effective method for off-design simulation of modern aircraft piston engines, AIAA Modeling and Simulation Technologies Conference and Exhibit; Honolulu, HI, United States, 18 August 2008 through 21 August 2008, Code 83207, 2008, Article number 2008-7095.

[23] L. Piancastelli, L. Frizziero, G. Zanuccoli, N. E. Daidzic and I. Rocchi, A comparison between CFRP and 2195-FSW for aircraft structural designs, Int. J. Heat Tech. 31(1) (2013), 17-24.

[24] L. Piancastelli, L. Frizziero, N. E. Daidzic and I. Rocchi, Analysis of automotive diesel conversions with KERS for future aerospace applications, Int. J. Heat Tech. 31(1) (2013), 143-154.

[25] L. Piancastelli, L. Frizziero and I. Rocchi, An innovative method to speed up the finite element analysis of critical engine components, Int. J. Heat Tech. 30(2) (2012), 127-132.

[26] L. Piancastelli, L. Frizziero and I. Rocchi, Feasible optimum design of a turbocompound diesel Brayton cycle for diesel-turbo-fan aircraft propulsion, Int. J. Heat Tech. 30(2) (2012), 121-126. 
[27] L. Piancastelli, L. Frizziero, S. Marcoppido, A. Donnarumma and E. Pezzuti, Fuzzy control system for recovering direction after spinning, Int. J. Heat Tech. 29(2) (2011), 87-93.

[28] L. Piancastelli, L. Frizziero, S. Marcoppido, A. Donnarumma and E. Pezzuti, Active antiskid system for handling improvement in motorbikes controlled by fuzzy logic, Int. J. Heat Tech. 29(2) (2011), 95-101.

[29] L. Piancastelli, L. Frizziero, E. Morganti and E. Pezzuti, Method for evaluating the durability of aircraft piston engines, Walailak J. Sci. Tech. 9(4) (2012), 425-431.

[30] L. Piancastelli, L. Frizziero, E. Morganti and A. Canaparo, Embodiment of an innovative system design in a sportscar factory, Far East J. Electronics and Communications 9(2) (2012), 69-98.

[31] L. Piancastelli, L. Frizziero, E. Morganti and A. Canaparo, The electronic stability program controlled by a fuzzy algorithm tuned for tyre burst issues, Far East $\mathrm{J}$. Electronics and Communications 9(1) (2012), 49-68.

[32] L. Piancastelli, L. Frizziero, I. Rocchi, G. Zanuccoli and N. E. Daidzic, The C-triplex approach to design of CFRP transport-category airplane structures, Int. J. Heat Tech. 31(2) (2013), 51-59.

[33] L. Frizziero and I. Rocchi, New finite element analysis approach, Far East J. Electronics and Communications 11(2) (2013), 85-100.

[34] L. Piancastelli, L. Frizziero and E. Pezzuti, Aircraft diesel engines controlled by fuzzy logic, ARPN J. Eng. Appl. Sci. 9(1) (2014), 30-34.

[35] L. Piancastelli, L. Frizziero and E. Pezzuti, KERS applications to aerospace diesel propulsion, ARPN J. Eng. Appl. Sci. 9(5) (2014), 807-818. 